\title{
MARQUES, Ana Martins. A vida submarina. Belo Horizonte: Scriptum, 2009. 144 p.
}

Janine Resende Rocha Universidade Federal de Minas Gerais

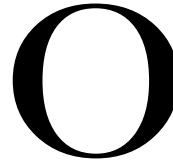

imperativo "Para o leitor ler de/vagar" ${ }^{1}$ inscreve no título do poema de Herberto Helder a lentidão como código e a errância do leitor, por assim dizer. O título condiz com uma profícua teoria da poesia, mesmo que condensada, segundo a qual o significante poético prima por um sentido permanentemente ausente, ou seja, um sentido nímio, que se desloca, que se recria, que se renova-sendo, assim, um sentido em movimento. Esse sentido implica um caráter assimétrico, pois a doação de sentido obriga a produção de uma diferença entre a expressão literária e a da leitura, uma vez que o sentido não é imanente ao texto. Tal caráter mostra-se ainda mais aguçado no caso do texto poético, que distingue melhor o "diálogo com a ausência"2 ao acentuar a intransitividade como característica, instituída pela linguagem poética e por aspectos não semânticos dessa linguagem, como som e ritmo.

O corolário dessa rápida reflexão é que a poesia explora mundos muito singulares, como Ana Martins Marques orquestra nos poemas reunidos em $A$ vida submarina, seu livro de estréia, em que a autora abraça a lentidão do poema, declarada no dístico de "Relógios":

${ }^{1}$ HELDER. Para o leitor ler de/vagar. In: HELDER. Ou o poema contínuo, p. 128-131.

${ }^{2}$ PAZ. $O$ arco e a lira, p. 15. 
Nos poemas o ponteiro dos segundos é mais lento que o das horas.

Os mundos orquestrados por Ana proclamam o "hábito feliz das palavras" numa dicção intimista e confessional, encenada - à maneira de Ana Cristina Cesar - em "Confissão", "Bilhete" e "Diário (verão de 2007)", mas igualmente cintilante nos demais poemas, que se nutrem de decla-raçōes, escrevem desenhos, rastreiam memórias, personalizam listas e definições, revelam segredos e "pensamentos submarinos".

Refletido no gesto poético, esse hábito incentiva a metalinguagem, mote da seção "Barcos de papel", a primeira do livro, em que o eu-lírico constitui o poema como circunscrição reflexiva que se apresenta como medida da incompreensão, do risco, do incomensurável, do vazio e do amor. Esses parâmetros confluem para poemas que, ao longo das demais sessóes, possuem como aparato um campo semântico que reitera o dia e a noite - cuja contigüidade, neste caso, torna-se periclitante-, o mar com sua vida marítima, as sensaçōes do corpo, a memória, a falta e o silêncio.
Em $A$ vida submarina, a engrenagem poética pretende um elo entre a episteme do mundo e a epiderme do corpo, como explicita o poema "Dardo", da seção intitulada "Episteme \& epiderme":

Existe o corpo, o eixo dos joelhos, as dobras, a força teatral dos membros, $\mathrm{o}$ o extremo silêncio, gosto acre, as mãos pendentes. Existe o mundo, as savanas e o iceberg, as horas velozes, o falcão, o crescimento secreto das plantas, o repouso dos objetos que envelhecem no uso, sem dor. Existe o poema, um dardo atirado a coisas mínimas, à noite, às cicatrizes.

Um secreto amor os une, as mãos na água, a memória do verão, o poema ao sol.

"Dardo" é um poema significativo não só por consagrar o diálogo entre mundo, corpo e poesia, mas também por matizá-lo: trata-se de um colóquio que privilegia o recôndito -exaltado nos imperiosos chamados do mar e da noite -, o detalhe, o esvaído, o sobressalto. 
A instância poética confidencia a vivência do desconcerto sentido pelo eu-lírico, condição que estabelece um contraste entre o "hábito feliz das palavras" e o espanto suscitado pelo mundo, visto como "estranho" e "imperfeito". Contudo, ao atender aos chamados do mar e da noite, $\mathrm{o}$ poema permite que o eu-lírico caminhe rente ao imponderável, trilha consumada em "Noite adentro", em que a congruência entre o mar e a noite é evidenciada:

Atado a um barco na noite o sono curva-se sobre si mesmo, entregue ao movimento secreto das ondas.

\section{[...]}

Neste quarto, noite adentro, percebe-se a presença perturbadora do mar: nas estantes, nos tapetes, nos móveis Nas paredes lisas de cansaço. submersos. Sou jogada no sono de um sonho a outro, lançada entre corais, como um peixe que dorme na ressaca.

Quando for preciso novamente acordar para o dia, o mar terá se afastado lentamente e voltado a ocupar o lugar onde o vejo pela janela esquerda do quarto.
$\mathrm{Na}$ "praia de palavras" dos poemas de $A$ vida submarina, o eulírico oscila entre mergulhos mais profundos, caros aos "escafandristas", e a "linha de arrebentação". A vida submarina aproxima, então, os universos do poema, da noite e do mar, estimula o eu-lírico a explorar mundos comumente inacessíveis e a transpor novas possibilidades, como a última estrofe de "A outra noite" expressa:

na noite do poema

outra noite

se anuncia.

No poema que dá título ao livro o eu-lírico urge em dizer que os domínios da vida submarina traduzem o "esplendor", o desejo e uma interioridade ancestral, que são incomunicáveis e que não irrompem na superfície.

De volta à linha de arrebentação, o fulgor cede passagem aos resíduos desfalecidos que o mar devolve:

Há um conhecimento na desordem: as ondas arrastam e trazem coisas para a praia - plástico, estrelas, conchas, cabelos. 
Oferendas para a luz

amor que acaba. O título do poema inútil de Helder mencionado no início do dia. desta resenha vale como uma boa orientação para o leitor, que, ao Ao emergir, o eu-lírico atém-se ao remanescente, que exala o tempo passado nos objetos envelhecidos, nas fotografias, nas lembranças, no explorar A vida submarina, de Ana Martins Marques, encontrará rotas em profusão.

\section{Referências bibliográficas}

HELDER, Herberto. Ou o poema contínuo. Lisboa: Assírio \& Alvim, 2004. $568 \mathrm{p}$.

PAZ, Octavio. O arco e a lira. Trad. Olga Savary. 2. ed. Rio de Janeiro: Nova Fronteira, 1982. 368 p. 